\title{
Catalysis, nanostructure and macroscopic property triangle in bioactive calcium-containing ceramic systems
}

\author{
Anikó Meiszterics a , Károly Havancsák ${ }^{\mathrm{b}}$, Katalin Sinkó ${ }^{\mathrm{a}, *}$ \\ a Institute of Chemistry, L. Eötvös University, Budapest, H-1117, Hungary \\ b Institute of Physics, L. Eötvös University, Budapest, H-1117, Hungary
}

\section{A R T I C L E I N F O}

\section{Article history:}

Received 13 April 2012

Received in revised form 3 October 2012

Accepted 4 December 2012

Available online 13 December 2012

\section{Keywords:}

Calcium silicate

Bioceramic

Solubility

Hardness

SEM

Sol-gel process

\begin{abstract}
A B S T R A C T
Calcium silicate ceramics are intended for application as long-term implant materials. In the present work, attention was paid to understand the correlations between the nanostructure (aggregate size, crystallinity, porosity) and the macroscopic properties (solubility in water and simulated body fluids, SBF; hardness) varying the chemical composition. Varying the catalyst (from a base to various acids) during the chemical synthesis was shown to significantly impact on the pore size, crystallinity and mechanical properties. The basic catalyst yields the ceramics with the highest mechanical strength. Ammonia used in 1.0 or 10.0 molar ratio results in bulk ceramics with parameters required for a biomedical application, good hardness (180-200 $\mathrm{HV})$ and low solubility (1-3\%) in water and in SBF. The fine porosity $(\sim 50 \mathrm{~nm})$ and homogeneous amorphous structure induce good mechanical character.
\end{abstract}

\section{Introduction}

The bioactive glass-ceramics and composites have been successfully used for the repair, reconstruction, and replacement of diseased or damaged parts of the body, especially bone or tooth. The most bioactive glasses and ceramics have been based on a silicate network due to the slight and slow solubility of silicates in human body fluid. Hereby these bioactive materials can be used as long-term implants. The bioactivity can be attributed to the bone bonding behavior. On the surface of bioactive materials, a biologically active carbonate hydroxyapatite (HCA) layer forms which provides the bonding interface with the living tissues. The growth rate of the HCA layer mainly depends on the bioactive glass composition and the porosity. The lower $\mathrm{SiO}_{2}$ and higher $\mathrm{CaO}$ contents result in a higher apatite layer growth, while the larger surface area ( $>$ natural bone porosity) and smaller pore size reduce the growth rates of the apatite layer [1-7]. Studying the "in vitro behavior" of the glasses indicates that the presence of phosphorus in the glass composition is not an essential requirement for the development of the HCA layer [1-8]. The apatite layer forms in the $\mathrm{P}_{2} \mathrm{O}_{5}$-free calcium silicate glasses using the phosphorus content present in the in vitro solution.

The gel-derived ceramics have been demonstrated to have better bioactivity than melt-quenched ceramics [9-13]. The better bioactivity can be explained by the great differences in the textural properties (e.g. in the porosity) of the gel- and melt-derived materials [11-13] and the better homogeneity, purity and amorphous feature of the sol-

\footnotetext{
* Corresponding author. Tel.: + 361 3722500; fax: + 3613722592

E-mail address: sinko@chem.elte.hu (K. Sinkó).
}

gel ceramics [11-16]. Furthermore, the amount and the position of crystalline particles can be much easier controlled via sol-gel than melting processes.

In our previous work, acid- or base-catalyzed sol-gel routes have been developed for the synthesis of calcium silicate systems $[17,18]$. The effect of the chemical composition, notably the catalysts on the bond systems has been investigated [19]. The present work focuses on the determination of the correlations between the ceramic nanostructure (particle size, crystallinity, and porosity) and the macroscopic properties (solubility in distilled water and simulated body fluids; hardness) achieved by using various catalysts (ammonia, acetic acid, and phosphoric acid). Dynamic light scattering (DLS) and scanning electron microscopy (SEM) provide the size characterization. The crystalline phases, morphology, and chemical composition of the particles with different shapes have been analyzed by X-ray diffraction (XRD), SEM, Fourier transform infrared spectroscopy (FTIR), and energy dispersive X-ray spectrometer (EDX).

\section{Experimental}

\subsection{Materials and gel synthesis}

The calcium silicate gel samples were produced by sol-gel technique starting from tetraethoxysilane (TEOS), $\left(\mathrm{Si}\left(\mathrm{OC}_{2} \mathrm{H}_{5}\right)_{4}, 98 \%\right.$, Aldrich) and calcium nitrate tetrahydrate, $\left(\mathrm{Ca}\left(\mathrm{NO}_{3}\right)_{2} \cdot 4 \mathrm{H}_{2} \mathrm{O}, 99 \%\right.$, Reanal) as precursors; 1-propanol (at. Aldrich) as solvent; ammonia (25\% aqueous solution, Reanal), acetic acid (99-100\%, Reanal) and phosphoric acid (85\% aqueous solution, Reanal) as catalysts. The syntheses of materials were 
carried out by hydrolysis and polycondensation in an organic solution of stoichiometric amounts of the precursors. The rate of the catalyst concentrations (0.50-10.0 mol catalyst/Si) was varied during this synthesis series. The gelation time of starting organic solution was $1 \mathrm{~h}$ in basic $\left(\mathrm{NH}_{3}\right.$ solution) or in phosphoric acid catalyzed processes, and $24 \mathrm{~h}$ in acidic solution (acetic acid). The aging as well as the drying processes were performed at $80{ }^{\circ} \mathrm{C}$ [8-10]. The heat treatment i.e. the sintering of ceramic powders was conducted in two steps, first at $600{ }^{\circ} \mathrm{C}(30 \mathrm{~min})$ and after pressing the pellets (uniaxial pressing at 24.5-39.2 MPa for $15-20 \mathrm{~min} /$ pellets $)$ at $700{ }^{\circ} \mathrm{C}\left(3 \mathrm{~h}, 100{ }^{\circ} \mathrm{C} / \mathrm{min}\right.$ heating and $20{ }^{\circ} \mathrm{C} / \mathrm{min}$ cooling rates).

\subsection{Characterization methods}

The aggregate size of ceramics powders has been determined by dynamical light scattering (DLS) method. DLS measurements were performed by means of an equipment (Brookhaven) consisting of a $\mathrm{BI}-200 \mathrm{SM}$ goniometer and a BI-9000AT digital correlator. An argon-ion laser (Omnichrome, model 543AP) operating at $488 \mathrm{~nm}$ wavelength and emitting vertically polarized light was used as the light source. The signal analyzer was used in real-time "multi tau" mode. In this mode the time axis was logarithmically spaced over an appropriate time interval and the correlator used 218 time channels. The pinhole was $100 \mu \mathrm{m}$. The particles were generally dispersed in ethanol for DLS measurements instead of distilled water in order to avoid the aggregation of the particles in distilled water. The number-weighted particle size distribution was detected by DLS.

The particle size and morphology of ceramic powders and sintered pellets have been studied by a FEI Quanta 3D FEG scanning electron microscope (SEM). The SEM images were prepared by the EverhartThornley secondary electron detector (ETD), its ultimate resolution is $1-2 \mathrm{~nm}$, and the accelerating voltage is $15.0 \mathrm{kV}$. Since the conductance of the particles investigated is high enough to remove the electric charge accumulated on the surface, the SEM images were performed in high vacuum without any coverage on the specimen surface. For the best SEM visibility, the particles were deposited on a HOPG (graphite) substrate surface. SEM combined with energy disperse X-ray spectroscopy (EDX) is mainly applied for spatially resolved chemical analysis of bulk samples.

Wide-angle $x$-ray scattering (WAXS) were detected with a 1D MYTHEN detector in HASYLAB of DESY (Hamburg). The WAXS data were collected over the $2 \theta$-range of $7-30^{\circ}$ with a step size $0.0212^{\circ}$. Identification of phases was achieved by comparing the diffraction patterns with the standard PDF cards.

The mechanical properties of bulk ceramics were compared with Vickers hardness measurements. The compressed tablets were tested with various instruments (an Akashi Microhardness tester, Anton Paar Microhardness tester MHT 4, and Shimadzu DUH-202 tester). A pyramidal diamond indenter was applied to the tablet surface under a load of $0.5-2 \mathrm{~N}$ for $15 \mathrm{~s}$. The tests were repeated at three different places 5-20 times for each sample.

The surface area and porosity of ceramic samples were characterized by $\mathrm{CCl}_{4}$ sorption analysis at $25^{\circ} \mathrm{C}$ on an autosorb computer controlled surface analyzer (AUTOSORB-1, Quantachrome or ASAP 2010 Micrometrics). Each sample was degassed for $12 \mathrm{~h}$ prior to analysis.

The solubility of the ceramics has been investigated in distilled water as well as in simulated body fluid (SBF) [20]. In all cases the sintered bulk samples were soaked for 1-14 days in distilled water and for 3 days in SBF. The drying process took for $2 \mathrm{~h}$ at $180{ }^{\circ} \mathrm{C}$ and $2 \mathrm{~h}$ at $700{ }^{\circ} \mathrm{C}$ after distilled water treatment and for 10 days at room temperature after dipping in SBF, respectively. Parallel tests have been carried out on ten samples. Weight changes, chemical surface modification, and the ions eluted into solution (in tissue culture water after 7 days) were fully analyzed.

The ions dissolved in distilled water were analyzed with total reflection X-ray fluorescence (TXRF) spectroscopy. The TXRF measurements were performed with an Atomika 8030C (FEI Co.) instrument. The influence of SBF soaking on the surface was monitored by attenuated total reflectance (ATR) Fourier transform infrared (FTIR) spectroscopy. The FTIR measurements were performed on Bruker IFS 55 instrument with diamond ATR head (PIKE technology). The infrared spectra were collected over the range of $4000-550 \mathrm{~cm}^{-1}$ at a resolution of $0.5 \mathrm{~cm}^{-1}$.

\section{Result and discussion}

The calcium silicate ceramic systems were synthesized by acid- or base-catalyzed sol-gel routes $[17,18]$. A Ca- and Si-containing colloid (gel or sol) systems form in the first step of the sol-gel method. The ceramic products can be obtained by drying and sintering processes from the gel system. The main reactions of the gelation are the hydrolysis and condensation. The hydrolysis and condensation reactions require acid or base catalysis $[17,18]$.

The previous research has studied the effect of the chemical parameters (e.g. catalysis, $\mathrm{Ca} / \mathrm{Si}$ and catalyst/Si ratios) and the heat treatment on the bond systems and aggregate structures. The acid-catalyzed reactions produce a gel system with randomly branched network arising from the fast hydrolysis. The base-catalyzed reactions yield a sol system built up from aggregates due to longer hydrolysis time, which can provide the possibility for the aggregation of particles into the most thermodynamically stable arrangement [19]. The $\mathrm{NH}_{3}$ catalyst favors the formation of $=\mathrm{Si}(\mathrm{OSi})_{2}$ units $(\mathrm{SiO})_{2} \mathrm{Si}\left(\mathrm{O}^{-}\right)_{2}$ or $(\mathrm{SiO})_{2} \mathrm{Si}(\mathrm{OH})_{2}$. The $\mathrm{Ca}$ ions prefer the bond to $=\mathrm{Si}(\mathrm{OSi})_{2}$ units [19]. The Ca ions bond not only to the silicate matrix or silicate anions in a crystalline phase, but also to the carbonate as well as $\mathrm{OH}$ ions in the range of $160-500{ }^{\circ} \mathrm{C}$. According to the XRD data, $\mathrm{CaO}$ does not form in these sol-gel derived ceramics up to $1000^{\circ} \mathrm{C}$.

\subsection{Comparison of various types of catalyst}

In Table 1, the porosity data and the particle sizes represent the structural parameters; while the Vickers hardness values (HV) the mechanical properties. For better comparison, the samples of presented investigations were synthesized with the same compositions (1:1:1 molar ratios of $\mathrm{Si} / \mathrm{Ca} / \mathrm{catalyst}$ ) and sintered at $700{ }^{\circ} \mathrm{C}$, only the type of catalysts was varied.

The ceramic products prepared by base catalysis possess the best mechanical strength (around $200 \mathrm{HV}$ ); this result is promising for a biomedical application. The sample of phosphoric acid catalysis shows altering HV values (on average $120 \mathrm{HV}$ ) due to the inhomogeneous phase composition (Fig. 1). The acetic acid catalysis produces low HV values (42-52 HV).

The big differences between the HV data may be explained by the porosity (Table 1) and the crystalline phases. The porosity of the ceramic systems is one of the important features with respect to the medical application. For comparison, the average specific surface areas of the cancellous and cortical human bone are $50-100 \mathrm{~m}^{2} \mathrm{~g}^{-1}$ $[21,22]$ and $2-40 \mathrm{~m}^{2} \mathrm{~g}^{-1}[21,23,24]$, respectively. The total porosity

Table 1

Structural and mechanical data of ceramic samples synthesized with different catalysts.

\begin{tabular}{llll}
\hline Measurements & Ammonia & Acetic acid & $\begin{array}{l}\text { Phosphoric } \\
\text { acid }\end{array}$ \\
\hline $\begin{array}{l}\text { Vickers hardness (HV) } \\
\text { Porosity (\%) (SEM) }\end{array}$ & $190 \pm 20$ & $47 \pm 5$ & $120 \pm 50$ \\
$\begin{array}{c}\text { Specific surface area }\left(\mathrm{m}^{2} \mathrm{~g}^{-1}\right) \\
\quad\left(\mathrm{CCl}_{4} \text { adsorption) }\right.\end{array}$ & $17 \pm 3$ & $8 \pm 2$ & $15 \pm 2$ \\
$\begin{array}{l}\text { Pore size (range/average in } \mathrm{nm}) \\
\quad(\mathrm{SEM})\end{array}$ & $20-240 / 50$ & $20-2000 / 165$ & $40-1500 / 310$ \\
$\begin{array}{l}\text { Particle size (range/average in } \mathrm{nm}) \\
\quad(\mathrm{DLS})\end{array}$ & $50-180 / 90$ & $80-120 / 100$ & $150-600 / 300$ \\
$\begin{array}{l}\text { Particle size (range/average in } \mathrm{nm}) \\
(\mathrm{SEM})\end{array}$ & $45-120 / 75$ & $30-110 / 90$ & $90-180 / 119$ \\
\hline
\end{tabular}




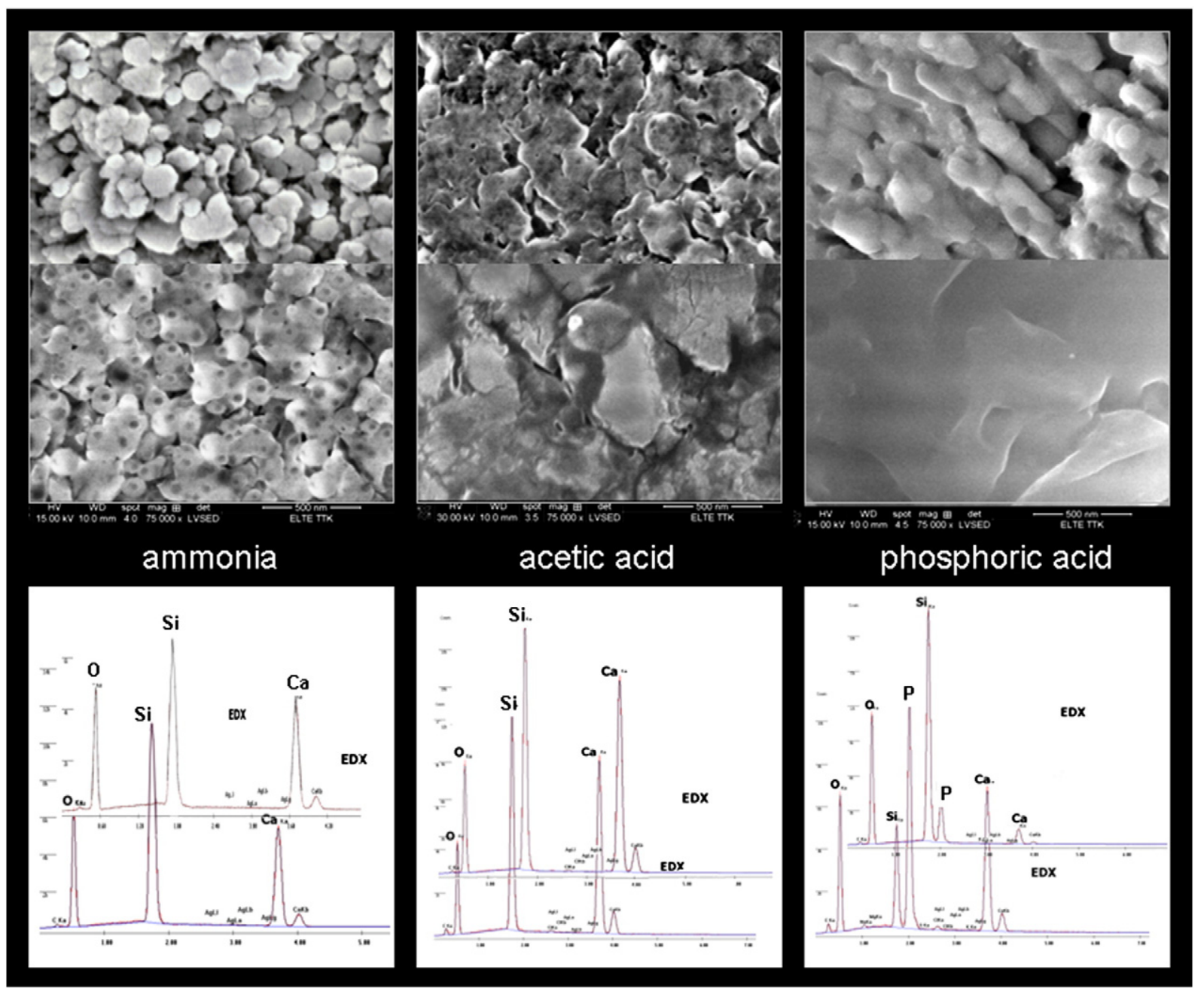

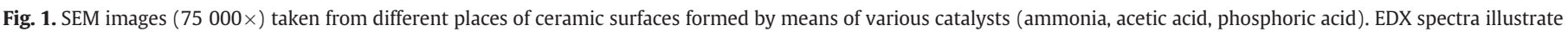
homogeneous $\left(\mathrm{NH}_{3}, \mathrm{HAc}\right)$ or inhomogeneous (phosphoric acid) chemical composition of the surfaces.

of the cancellous and cortical bone is $30-90 \%$ and $5-30 \%$ [25-29], respectively. All porosity data fit to the porosity range of natural bone. The highest porosity and the largest specific surface area $(\approx 17 \%$, $19 \mathrm{~m}^{2} \mathrm{~g}^{-1}$ ) could be detected in the samples prepared with ammonia. The ammonia-catalyzed sample contains many fine pores; the mean pore size is about $50 \mathrm{~nm}$. The systems obtained in acidic medium possess the lowest value $\left(8 \%, 7 \mathrm{~m}^{2} \mathrm{~g}^{-1}\right)$. The acetic acid-catalyzed sample can be characterized by less, but larger and polydisperse pores (20-2000 nm, on average $165 \mathrm{~nm}$ ). The polydisperse larger pores reduce dramatically the mechanical strength (e.g. $~ 190 \mathrm{HV}$ at $20-240 \mathrm{~nm}$ pore size and $\sim 47 \mathrm{HV}$ at $20-2000 \mathrm{~nm})$. The porosity of the phosphorous containing samples is slightly lower $\left(\approx 15 \%, 14 \mathrm{~m}^{2} \mathrm{~g}^{-1}\right)$ than that of ammonia catalyzed sample. Whereas, the sample of phosphoric acid has the largest (around $310 \mathrm{~nm}$ ) but less polydisperse pores, its mean Vickers hardness data is much better than that of acetic acid owing to the glassy phase (Fig. 1). The large pores are present rather in the aggregated part of the bulk ceramics than in glass phases decreasing the mechanical properties of the phase built up from aggregates. Otherwise, the compact and poreless glass phase has a good hardness.

The size of the particles, which build up the ceramic structures, has no observable effect on the properties. There is only a slight difference between the particles of base and acetic acid catalysis: 90 (base), 100 (acid) $\mathrm{nm}$ before the sintering and 75 (base), 90 (acid) nm after the sintering, respectively) (Table 1 ). In the sample of the phosphoric acid catalysis, the largest particles $(300 \mathrm{~nm})$ can be detected by DLS before the sintering. After the sintering much lower sizes (119 nm) are presented with SEM. That also indicates that a significant melting process occurred during the sintering at $700{ }^{\circ} \mathrm{C}$.

Comparing the crystalline structures obtained by various catalysts, the phosphorous-containing systems possess the largest volume of crystals; $\beta$ - and $\gamma-\mathrm{Ca}_{2} \mathrm{P}_{2} \mathrm{O}_{7}$ phases at $700{ }^{\circ} \mathrm{C}$ (Fig. 2). On the one hand, the phosphorus content plays an important role in the crystallization of the glasses; it induces the crystallization of calcium phosphate phases. On the other hand, the higher P ratio $(>0.5 \mathrm{~mol} \mathrm{P} / \mathrm{Ca})$ furthers even the melting process. The synthesis with $2 \mathrm{~mol} \mathrm{P} / \mathrm{Ca}$ leads to the formation of a glass foam at $600{ }^{\circ} \mathrm{C}$. Glassy lenses (Fig. 1) are silicate-based glass with $30 \%$ phosphorous and $10 \%$ calcium oxides content (EDX). In the system of 1:1:1 molar ratio of $\mathrm{Ca} / \mathrm{Si} / \mathrm{P}, \gamma-\mathrm{Ca}_{2} \mathrm{P}_{2} \mathrm{O}_{7}$ appears first as a crystalline phase during the heating, its amount continually decreases with the rising temperature and turns into $\beta$ and $\gamma-\mathrm{Ca}_{2} \mathrm{P}_{2} \mathrm{O}_{7}$ phases at around $500{ }^{\circ} \mathrm{C}$. A small amount of $\mathrm{CaCO}_{3}$ and $2 \mathrm{Ca}_{2} \mathrm{SiO}_{4} \cdot \mathrm{Ca}_{3}\left(\mathrm{PO}_{4}\right)_{2}$ can be identified between 300 and $500{ }^{\circ} \mathrm{C}$. Moreover, the presence of phosphorus produces a heterogeneous distribution of defects in the ceramic bodies reducing the mechanical strength. In the acetic acid-catalyzed systems, a small amount of crystalline phases $\left(\mathrm{CaCO}_{3}\right.$ and $\left.\mathrm{SiO}_{2}\right)$ can be demonstrated by XRD or WAXS between 80 and $500{ }^{\circ} \mathrm{C}$. A new calcium silicate phase, $\beta-\mathrm{Ca}_{2} \mathrm{SiO}_{4}$ develops already at low temperature $\left(300{ }^{\circ} \mathrm{C}\right)$ that transforms to wollastonite $\left(\mathrm{CaSiO}_{3}\right)$ at around $900{ }^{\circ} \mathrm{C}$. The ammonia-catalyzed systems are principally amorphous. Only a slight amount of $\beta-\mathrm{Ca}_{2} \mathrm{SiO}_{4}$ may be 


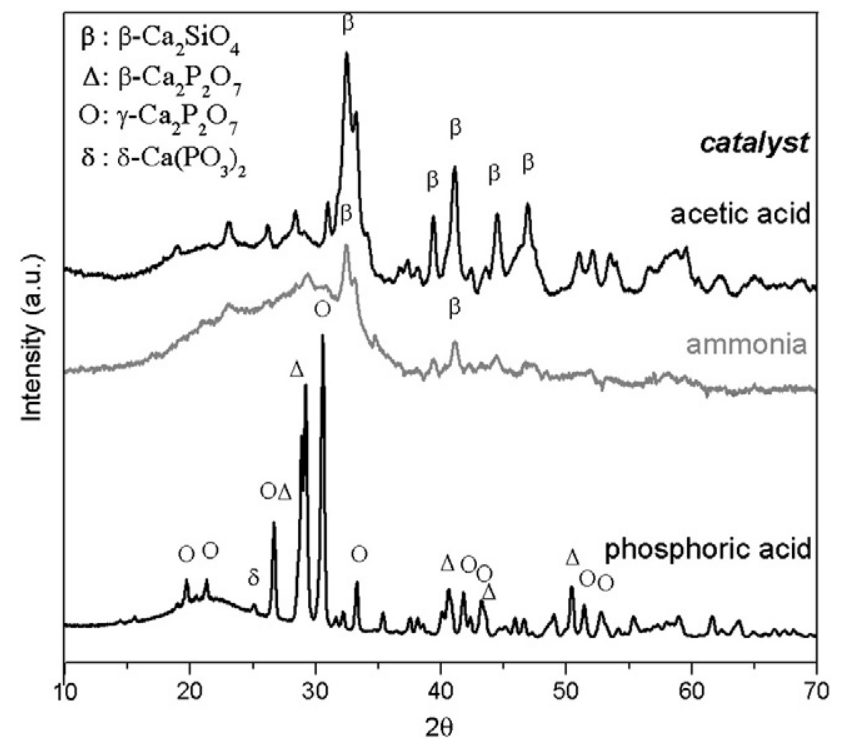

Fig. 2. X-ray diffraction patterns of calcium silicate systems synthesized with different catalysts and heated at $700{ }^{\circ} \mathrm{C}$.

Table 2

Temperature range of the crystalline phases in the function of catalysis.

\begin{tabular}{|c|c|c|c|}
\hline Temperature range $\left({ }^{\circ} \mathrm{C}\right)$ & Acetic acid & Ammonia & Phosphoric acid \\
\hline 80 & $\mathrm{CaCO}_{3}$ & \multirow[t]{3}{*}{ Amorphous } & $\gamma-\mathrm{Ca}_{2} \mathrm{P}_{2} \mathrm{O}_{7}$ \\
\hline 140 & $\mathrm{SiO}_{2}$ & & $\mathrm{CaCO}_{3}$ \\
\hline 300 & & & $2 \mathrm{Ca}_{2} \mathrm{SiO}_{4} \cdot \mathrm{Ca}_{3}\left(\mathrm{PO}_{4}\right)_{2}$ \\
\hline \multirow[t]{4}{*}{500} & $\mathrm{CaCO}_{3}$ & $\mathrm{CaCO}_{3}$ & $\gamma-\mathrm{Ca}_{2} \mathrm{P}_{2} \mathrm{O}_{7}$ \\
\hline & $\mathrm{SiO}_{2}$ & $\mathrm{SiO}_{2}$ & $\beta-\mathrm{Ca}_{2} \mathrm{P}_{2} \mathrm{O}_{7}$ \\
\hline & $\beta-\mathrm{Ca}_{2} \mathrm{SiO}_{4}$ & & $\mathrm{CaCO}_{3}$ \\
\hline & \multirow{3}{*}{$\beta-\mathrm{Ca}_{2} \mathrm{SiO}_{4}$} & & $2 \mathrm{Ca}_{2} \mathrm{SiO}_{4} \cdot \mathrm{Ca}_{3}\left(\mathrm{PO}_{4}\right)_{2}$ \\
\hline 700 & & \multirow{2}{*}{$\begin{array}{l}\text { Amorphous } \\
\beta-\mathrm{Ca}_{2} \mathrm{SiO}_{4}\end{array}$} & $\begin{array}{l}\mathrm{P}-\mathrm{Cd}_{2} \mathrm{~F}_{2} \mathrm{U}_{7} \\
\gamma-\mathrm{Ca}_{2} \mathrm{P}_{2} \mathrm{O}_{7}\end{array}$ \\
\hline 800 & & & $\delta-\mathrm{Ca}\left(\mathrm{PO}_{3}\right)_{2}$ \\
\hline 900 & \multirow[t]{2}{*}{$\mathrm{CaSiO}_{3}$} & \multirow[t]{2}{*}{$\mathrm{CaSiO}_{3}$} & \\
\hline$>900$ & & & $\begin{array}{l}\beta-\mathrm{Ca}_{2} \mathrm{P}_{2} \mathrm{O}_{7} \\
\mathrm{SiO}_{2}\end{array}$ \\
\hline
\end{tabular}

observed between 700 and $900{ }^{\circ} \mathrm{C}$ (Table 2). Similar to the acetic acid-catalyzed systems, $\beta-\mathrm{Ca}_{2} \mathrm{SiO}_{4}$ changes to a calcium metasilicate phase at about $900{ }^{\circ} \mathrm{C}$.

\subsection{Material features in the function of ammonia concentration}

Only the ammonia-catalyzed bulk ceramics can be utilized as a ceramic body of long-term implants owing to their good bioactivity, sufficient mechanical strength, and low solubility (see in Section 3.3). The phosphorus content provided by $\mathrm{H}_{3} \mathrm{PO}_{4}$ increases drastically the solubility (discussed further in Section 3.3), while the acetic acid catalysis yields ceramics with low mechanical strength. The previous examinations of the ammonia influence on the bond system have indicated a considerable change at $\geq 1$ molar ratio of $\mathrm{NH}_{3} / \mathrm{Ca}$. This ratio of catalyst is needed for achieving the $\mathrm{pH}$ required for the hydrolysis and condensation of TEOS and for the development of $\mathrm{Si}-\mathrm{OH}$ groups [19]. Thus, the present study focused on the investigations of 1.0-10.0 molar ratios of $\mathrm{NH}_{3} / \mathrm{Ca}$. The structural (porosity, pore and particle sizes) and mechanical parameters (hardness) are listed in Table 3 in the function of ammonia molar ratio. Significant differences can be observed in the Vickers hardness data. The application of terminal (1.0 or 10.0) ammonia molar ratios leaded to surprise results; that produced bulk ceramics with the largest hardness (140-350 HV, on average $180-190 \mathrm{HV}$ ). The intermediate ammonia molar ratios provided the bulk ceramics with less hardness (on average 110-120 HV). These data have been checked by three different Vickers hardness testers in order to approve the non-linear change (Fig. 3). The change of HV values can be interpreted by means of porosity, especially of pore size and crystallinity similar to the effect of the various types of catalyst (Table 3). The fine pores (on average $50 \mathrm{~nm}$ ) result in a good mechanical strength. At 3.0 or 5.0 ammonia molar ratio, the larger pores (on average $80-120 \mathrm{~nm}$ ) decrease strongly the hardness. The percent porosity and the particle sizes do not change unambiguously as a function of ammonia ratio (Table 3 ).

The difference in the hardness values can be interpreted by the crystalline phases. The in-situ WAXS and XRD measurements detected $\alpha$-quartz $\left(\mathrm{SiO}_{2}\right)$ and calcite $\left(\mathrm{CaCO}_{3}\right)$ as first crystalline phases in the ammonia-catalyzed systems during the heat treatment, in the range of 140 and $500{ }^{\circ} \mathrm{C}$ (Table 4). Both phases disappear simultaneously at around $500{ }^{\circ} \mathrm{C}$, indicating a reaction between them independent of the ammonia concentration. The character of the newly developed phase depends on the ammonia concentration. The use of 1.0 and 10.0 molar ratios leads directly to the formation of a temporary calcium silicate amorphous phase, which transforms to smaller crystals $\left(\beta-\mathrm{Ca}_{2} \mathrm{SiO}_{4}\right)$ only at higher temperature (700 and $\left.800{ }^{\circ} \mathrm{C}\right)$. The same crystalline phase $\left(\beta-\mathrm{Ca}_{2} \mathrm{SiO}_{4}\right)$ forms already above $500{ }^{\circ} \mathrm{C}$ in the samples of the intermediate molar ratios $(3,5)$. Above $800{ }^{\circ} \mathrm{C}, \beta$-dicalcium silicate turns into a crystalline phase of calcium metasilicates (e.g. wollastonite) in every sample. Fig. 4 depicts the $\mathrm{X}$-ray diffraction patterns for ceramic systems obtained by using various ammonia concentrations and heated at $700{ }^{\circ} \mathrm{C}$. The XRD curves represent a rising amorphous character for ammonia-catalyzed ceramic materials in the function of the increasing molar ratio.

\subsection{Soluble behavior of the sintered calcium-containing ceramic systems}

From the view point of medical application, the soluble behavior of the bulk ceramic samples possesses an outstanding relevance. The bulk ceramics sintered at $700{ }^{\circ} \mathrm{C}$ were soaked in distilled water as well as in simulated body fluids (SBF). The solubility in distilled water has been characterized by measurements of weight loss and analyzed for ionic content by TXRF after 7 days. The behavior of the bulk ceramics in SBF has been mostly analyzed by surface control (SEM, EDX, FTIR).

A weight loss of $3-4 \%$ in distilled water can be detected in the samples synthesized with acetic acid or ammonia catalyst (Table 5 and Fig. 5). These weight losses occur in 1-2 days and after that the bulks hold their weight. In order to determine the reason of weight loss, the chemical composition of distilled water has been analyzed by TXRF measurements observed after a period of soaking in water

Table 3

Structural and mechanical data of ceramic samples synthesized with various amounts of ammonia catalyst.

\begin{tabular}{|c|c|c|c|c|}
\hline \multirow[t]{2}{*}{ Measurements } & \multicolumn{4}{|c|}{ Molar ratio of $\mathrm{NH}_{3} / \mathrm{Ca}$} \\
\hline & 1.0 & 3.0 & 5.0 & 10.0 \\
\hline Vickers hardness (HV) & $150-240 / 190$ & $90-120 / 107$ & $100-180 / 120$ & $140-350 / 180$ \\
\hline Porosity (\%) (SEM) & $17 \pm 3$ & $15 \pm 2$ & $19 \pm 3$ & $20 \pm 3$ \\
\hline Pore size (range/average in nm) (SEM) & $20-240 / 50$ & $20-300 / 83$ & $10-300 / 120$ & $5-140 / 50$ \\
\hline Particle size (range/average in nm) (DLS) & $50-180 / 90$ & $30-180 / 85$ & $35-180 / 85$ & $30-300 / 110$ \\
\hline Particle size (range/average in nm) (SEM) & $45-120 / 75$ & $50-140 / 80$ & $45-134 / 80$ & $45-120 / 84$ \\
\hline
\end{tabular}




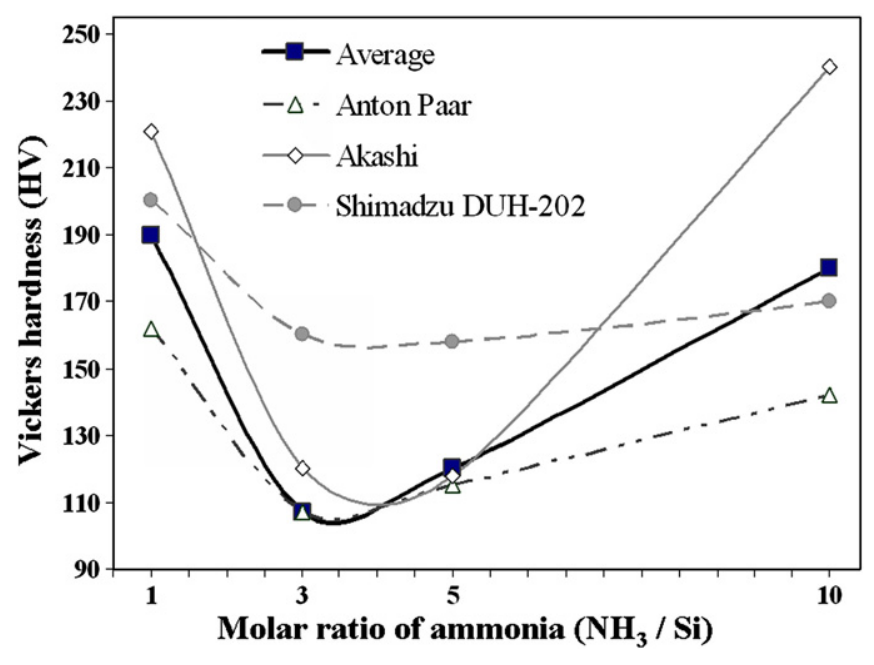

Fig. 3. Vickers hardness data measured by different instruments (Anton Paar Micro; Akashi Micro; Shimadzu DUH-202 hardness testers) in the function of ammonia concentration.

after 7 days (Table 6). In acetic acid-catalyzed ceramics, the weight loss $(\approx 4 \%)$ mostly arises from the dissolution of calcium ions ( $0.02 \mathrm{~g}$ Ca ions/g sample). The solution of the silicon atoms is negligible $\left(1.710^{-5} \mathrm{~g} / \mathrm{g}\right.$ sample). After soaking the samples synthesized in basic medium, not only calcium ions $\left(2.9 \cdot 10^{-3}-3.5 \cdot 10^{-3} \mathrm{~g} / \mathrm{g}\right.$ sample) but silicon atoms could also be detected $\left(1.7 \cdot 10^{-3} \mathrm{~g} / \mathrm{g}\right.$ sample $)$ in the distilled water solution. Considering these concentration data, the major part of the weight loss arises from the sintering defects, i.e. the fine particles can be released from ceramic surfaces. Only a minor part of the weight loss is the consequence of a real water solubility.

In contrast to these acetic acid- or ammonia-catalyzed ceramic materials, a larger and more or less continuous weight loss can be observed in the systems catalyzed by phosphoric acid (Table 5, Fig. 5). The weight change is faster in the first three days and it still continues slower in the second week (Fig. 5). The solubility of the ceramics increases drastically (from 10 to $48 \%$ ) by rising molar ratio of $\mathrm{Si} / \mathrm{P}$ (Table 5 ). The phosphorus-containing systems release mainly phosphorus $\left(3.7 \cdot 10^{-3} \mathrm{~g} / \mathrm{g}\right.$ sample) and calcium $\left(2.4 \cdot 10^{-3} \mathrm{~g} / \mathrm{g}\right.$ sample $)$ ions and only a slight volume of silicon $\left(3.6 \cdot 10^{-4} \mathrm{~g} / \mathrm{g}\right.$ sample) during the soaking (Table 6). The most removed calcium ions (generally $70-80 \%$ ) are substituted by $\mathrm{H}^{+}$ions. The silicon content dissolves as silicon-dioxide from the surface of the phosphoric acid-catalyzed samples.

The weight change of the bulk ceramics has also been investigated after a 3-day soaking in SBF. After soaking and drying, a lower weight growth can be observed; at $\mathrm{NH}_{3}(2-2.5 \%)$ and at acetic acid catalysis (5.0-5.5\%). The phosphoric acid-catalyzed samples produce low weight losses (2.0-2.5\%) by soaking in SBF due to the larger dissolution than the precipitation from SBF. The influence of the soaking in

Table 4

Temperature range of the crystalline phases in the function of ammonia concentration.

\begin{tabular}{|c|c|c|c|c|}
\hline \multirow[t]{2}{*}{ Temperature range $\left({ }^{\circ} \mathrm{C}\right)$} & \multicolumn{4}{|c|}{ Molar ratio of $\mathrm{NH}_{3} / \mathrm{Ca}$} \\
\hline & 1.0 & 3.0 & 5.0 & 10.0 \\
\hline 80 & Amorphous & Amorphous & Amorphous & $\mathrm{Ca}\left(\mathrm{NO}_{3}\right)_{2}$ \\
\hline 140 & $\mathrm{CaCO}_{3}$ & & $\mathrm{CaCO}_{3}$ & $\mathrm{CaCO}_{3}$ \\
\hline 500 & $\mathrm{SiO}_{2}$ & $\begin{array}{l}\mathrm{CaCO}_{3} \\
\mathrm{SiO}_{2}\end{array}$ & $\begin{array}{l}\mathrm{SiO}_{2} \\
\text { Amorphous }\end{array}$ & $\mathrm{SiO}_{2}$ \\
\hline $\begin{array}{l}600 \\
700\end{array}$ & $\begin{array}{l}\text { Amorphous } \\
\beta-\mathrm{Ca}_{2} \mathrm{SiO}_{4}\end{array}$ & $\beta-\mathrm{Ca}_{2} \mathrm{SiO}_{4}$ & $\beta-\mathrm{Ca}_{2} \mathrm{SiO}_{4}$ & Amorphous \\
\hline 800 & & & & \\
\hline $\begin{array}{l}900 \\
>900\end{array}$ & $\mathrm{CaSiO}_{3}$ & $\mathrm{CaSiO}_{3}$ & $\mathrm{CaSiO}_{3}$ & $\mathrm{CaSiO}_{3}$ \\
\hline
\end{tabular}

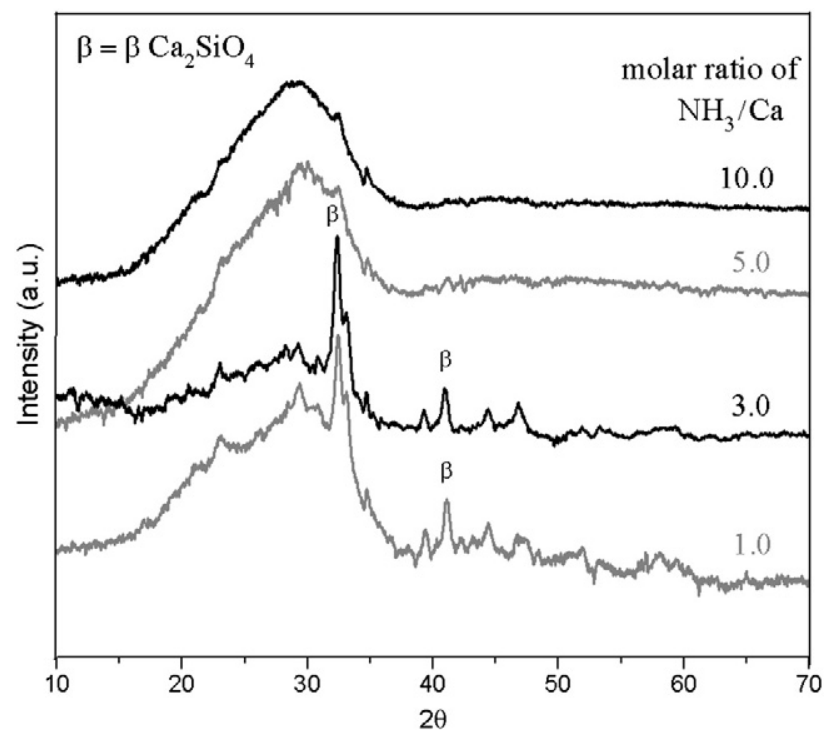

Fig. 4. X-ray diffraction patterns of calcium silicate systems synthesized by various amounts of ammonia catalyst.

SBF on the surfaces was compared by means of SEM images (Figs. 6-8) and the adsorbed compounds were identified by EDX analysis. The $\sim 5 \%$ weight growth of acetic acid-catalyzed sample occurred by soaking is derived mainly from calcium carbonate and in a smaller part from calcium phosphate and hydroxyapatite precipitation. The small white particles $(\sim 350 \mathrm{~nm})$ on the surfaces of acetic acid-catalyzed samples are calcium phosphate crystallites (Fig. 6). The phosphate precipitates are dispersed on the whole surface. The larger crystallites, the "rose" (60-120 $\mu \mathrm{m})$ proved to be calcium carbonate (Fig. 6).

In the ceramic systems catalyzed by ammonia, a weight growth of $2 \%$ can be observed. The precipitates dispersed overall on the ceramic surfaces are similar to that separated in the systems of acetic acid catalyst (Fig. 7). The small phosphate particles $(\sim 350 \mathrm{~nm})$ are dominant, while the large carbonate participates $(65-120 \mu \mathrm{m})$ are present only

Table 5

The time dependence of solubility in distilled water.

\begin{tabular}{|c|c|c|c|c|c|}
\hline $\begin{array}{l}\text { Molar ratio of } \\
\text { catalyst/Ca }\end{array}$ & $\begin{array}{l}\text { Days of } \\
\text { soaking }\end{array}$ & $\begin{array}{l}\text { Weight } \\
\text { loss \% }\end{array}$ & $\begin{array}{l}\text { Molar ratio of } \\
\text { catalyst/Ca }\end{array}$ & $\begin{array}{l}\text { Days of } \\
\text { soaking }\end{array}$ & $\begin{array}{l}\text { Weight } \\
\text { loss \% }\end{array}$ \\
\hline \multirow[t]{6}{*}{$\mathrm{NH}_{3} / \mathrm{Ca}=1$} & 1 & $3.4 \pm 0.4$ & \multirow[t]{6}{*}{$\mathrm{NH}_{3} / \mathrm{Ca}=1$} & 1 & $3.4 \pm 0.4$ \\
\hline & 2 & $3.5 \pm 0.5$ & & 2 & $3.5 \pm 0.5$ \\
\hline & 3 & $3.8 \pm 0.4$ & & 3 & $3.8 \pm 0.4$ \\
\hline & 4 & $3.4 \pm 0.3$ & & 4 & $3.4 \pm 0.3$ \\
\hline & 7 & $3.5 \pm 0.3$ & & 7 & $3.5 \pm 0.3$ \\
\hline & 14 & $3.8 \pm 0.3$ & & 14 & $3.8 \pm 0.3$ \\
\hline \multirow[t]{6}{*}{$\mathrm{CH}_{3} \mathrm{COOH} / \mathrm{Ca}=1$} & 1 & $4.3 \pm 0.5$ & \multirow[t]{6}{*}{$\mathrm{NH}_{3} / \mathrm{Ca}=3$} & 1 & $4.0 \pm 0.5$ \\
\hline & 2 & $4.4 \pm 0.5$ & & 2 & $3.3 \pm 0.5$ \\
\hline & 3 & $4.0 \pm 0.4$ & & 3 & $4.0 \pm 0.4$ \\
\hline & 4 & $4.4 \pm 0.3$ & & 4 & $3.7 \pm 0.4$ \\
\hline & 7 & $4.0 \pm 0.3$ & & 7 & $4.3 \pm 0.3$ \\
\hline & 14 & $4.9 \pm 0.5$ & & 14 & $4.4 \pm 0.3$ \\
\hline \multirow[t]{6}{*}{$\mathrm{H}_{3} \mathrm{PO}_{4} / \mathrm{Ca}=1$} & 1 & $7.9 \pm 0.6$ & \multirow[t]{6}{*}{$\mathrm{NH}_{3} / \mathrm{Ca}=5$} & 1 & $4.0 \pm 0.5$ \\
\hline & 2 & $8.5 \pm 0.7$ & & 2 & $3.7 \pm 0.5$ \\
\hline & 3 & $9.0 \pm 0.7$ & & 3 & $4.3 \pm 0.4$ \\
\hline & 4 & $8.9 \pm 0.6$ & & 4 & $5.0 \pm 0.5$ \\
\hline & 7 & $9.6 \pm 0.6$ & & 7 & $4.4 \pm 0.4$ \\
\hline & 14 & $10.4 \pm 0.7$ & & 14 & $4.5 \pm 0.5$ \\
\hline \multirow[t]{6}{*}{$\mathrm{H}_{3} \mathrm{PO}_{4} / \mathrm{Ca}=2$} & 1 & $40 \pm 4$ & \multirow[t]{6}{*}{$\mathrm{NH}_{3} / \mathrm{Ca}=10$} & 1 & $4.2 \pm 0.4$ \\
\hline & 2 & $43 \pm 4$ & & 2 & $4.3 \pm 0.4$ \\
\hline & 3 & $45 \pm 4$ & & 3 & $4.3 \pm 0.4$ \\
\hline & 4 & $45 \pm 4$ & & 4 & $4.0 \pm 0.4$ \\
\hline & 7 & $47 \pm 5$ & & 7 & $3.8 \pm 0.3$ \\
\hline & 14 & $48 \pm 5$ & & 14 & $3.9 \pm 0.4$ \\
\hline
\end{tabular}




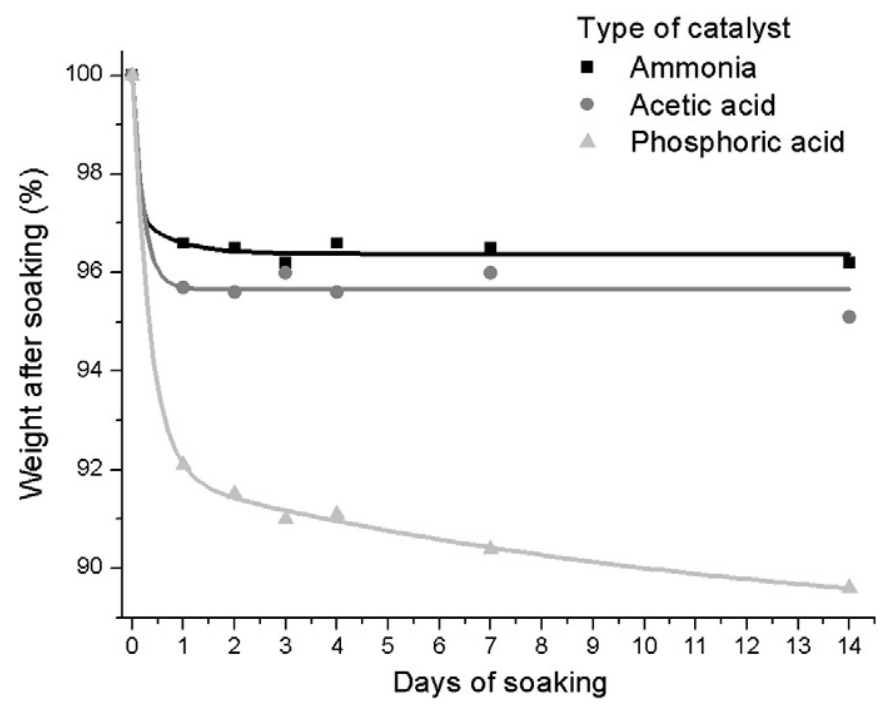

Fig. 5. Time dependence of solubility in distilled water.

Table 6

TXRF analysis of the chemical composition of water after a 7-day soaking.

\begin{tabular}{llll}
\hline Molar ratio of catalyst/Ca & $\mathrm{Ca}(\mathrm{g} / \mathrm{g})$ & $\mathrm{Si}(\mathrm{g} / \mathrm{g})$ & $\mathrm{P}(\mathrm{g} / \mathrm{g})$ \\
\hline 1.0 acetic acid & $2.0 \cdot 10^{-2}$ & $1.7 \cdot 10^{-5}$ & - \\
$1.0 \mathrm{H}_{3} \mathrm{PO}_{4}$ & $2.4 \cdot 10^{-3}$ & $3.6 \cdot 10^{-4}$ & $3.7 \cdot 10^{-3}$ \\
$1.0 \mathrm{NH}_{3}$ & $2.9 \cdot 10^{-3}$ & $1.7 \cdot 10^{-3}$ & - \\
$5.0 \mathrm{NH}_{3}$ & $3.4 \cdot 10^{-3}$ & $2.5 \cdot 10^{-3}$ & - \\
$10.0 \mathrm{NH}_{3}$ & $3.5 \cdot 10^{-3}$ & $2.3 \cdot 10^{-3}$ & - \\
\hline
\end{tabular}

in a small amount (Fig. 7). Hydroxyapatite precipitation is not carried out.

Relevant changes cannot be observed on the surface of the phosphoric acid-catalyzed samples (Fig. 8). Some phosphate precipitates can be monitored by SEM on certain parts of the surface (Fig. 8). The solubility of phosphate-containing materials is significantly less in SBF (2-3\%) than in pure water (8-10\%). The reason of that is the $\mathrm{Ca}^{2+}$ and $\mathrm{PO}_{4}^{3-}$ ions of SBF decreasing strongly the solubility. However, the precipitation from SBF must also be taken into account.

The FTIR spectra recorded before and after soaking in SBF verified the results of EDX measurements (Fig. 9). In the case of acetic acid and ammonia catalysis, new peaks appear in the FTIR spectra after a soaking in SBF, which can be associated to the phosphate group $\left(\mathrm{PO}_{4}^{3-}, 1080\right.$ and $1220 \mathrm{~cm}^{-1}$ ). Parallel with the absorption of phosphate groups, slight carbonation $\left(1440 \mathrm{~cm}^{-1}\right.$ and $\left.670 \mathrm{~cm}^{-1}\right)$ and hydration $\left(1645 \mathrm{~cm}^{-1}\right)$ processes can be identified. In the sample prepared by phosphoric acid, only slight changes can be detected by FTIR after the SBF-soaking. In the FTIR spectrum for the sample derived from the surface layer of an ammonia-catalyzed system, the absorption band of $\mathrm{Ca}-\mathrm{O}-\mathrm{Si}$ strongly reduces and the common band of $\mathrm{SiO}_{4}$ and $\mathrm{PO}_{4}\left(1077 \mathrm{~cm}^{-1}\right)$ increases. The decrease of the peak of $\mathrm{Ca}-\mathrm{O}-\mathrm{Si}\left(881 \mathrm{~cm}^{-1}\right)$ indicates the dissolution of the $\mathrm{Ca}^{2+}$ ions from the ceramic surface. The calcium ions dissolved in SBF solution are substituted by $\mathrm{H}^{+}$ion and produce silanol $(\mathrm{Si}-\mathrm{OH})$ groups on the ceramic surfaces. The substitution has been confirmed by the appearance of the $\mathrm{OH}$ band in the IR spectra (at 3734 and $1644 \mathrm{~cm}^{-1}$ ). The silanol group on the surface of biomaterials is reported to be essential for the formation of hydroxyapatite. The silanol group provides favorable sites for hydroxyapatite nucleation [9-13,20,30-34]. The hydroxyapatite-like layer ensures the good connection to the living tissues and increases hereby the bioactivity of ceramics.

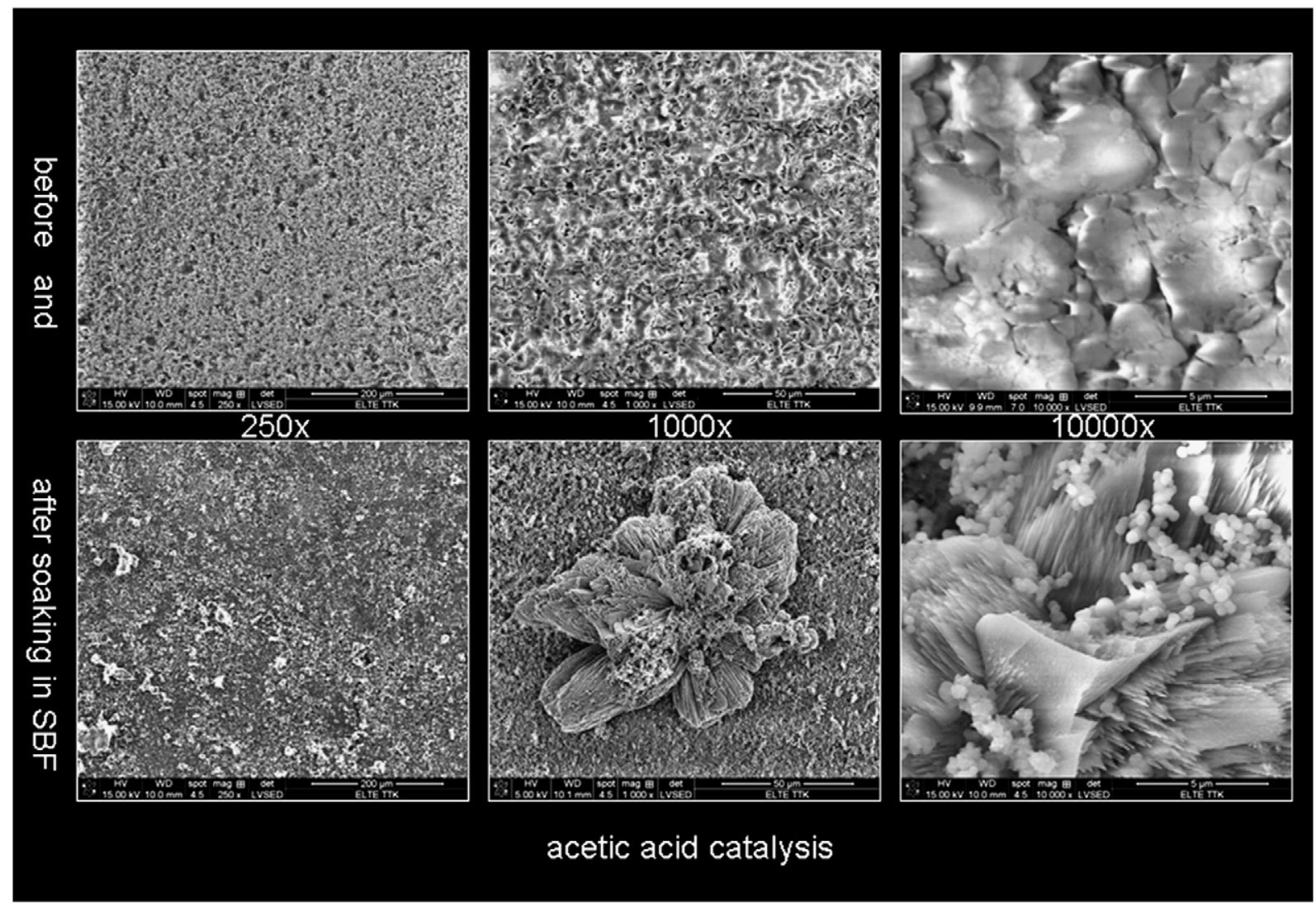

Fig. 6. SEM images of various magnifications for acetic acid-catalyzed samples before and after soaking in SBF for 3 days. 


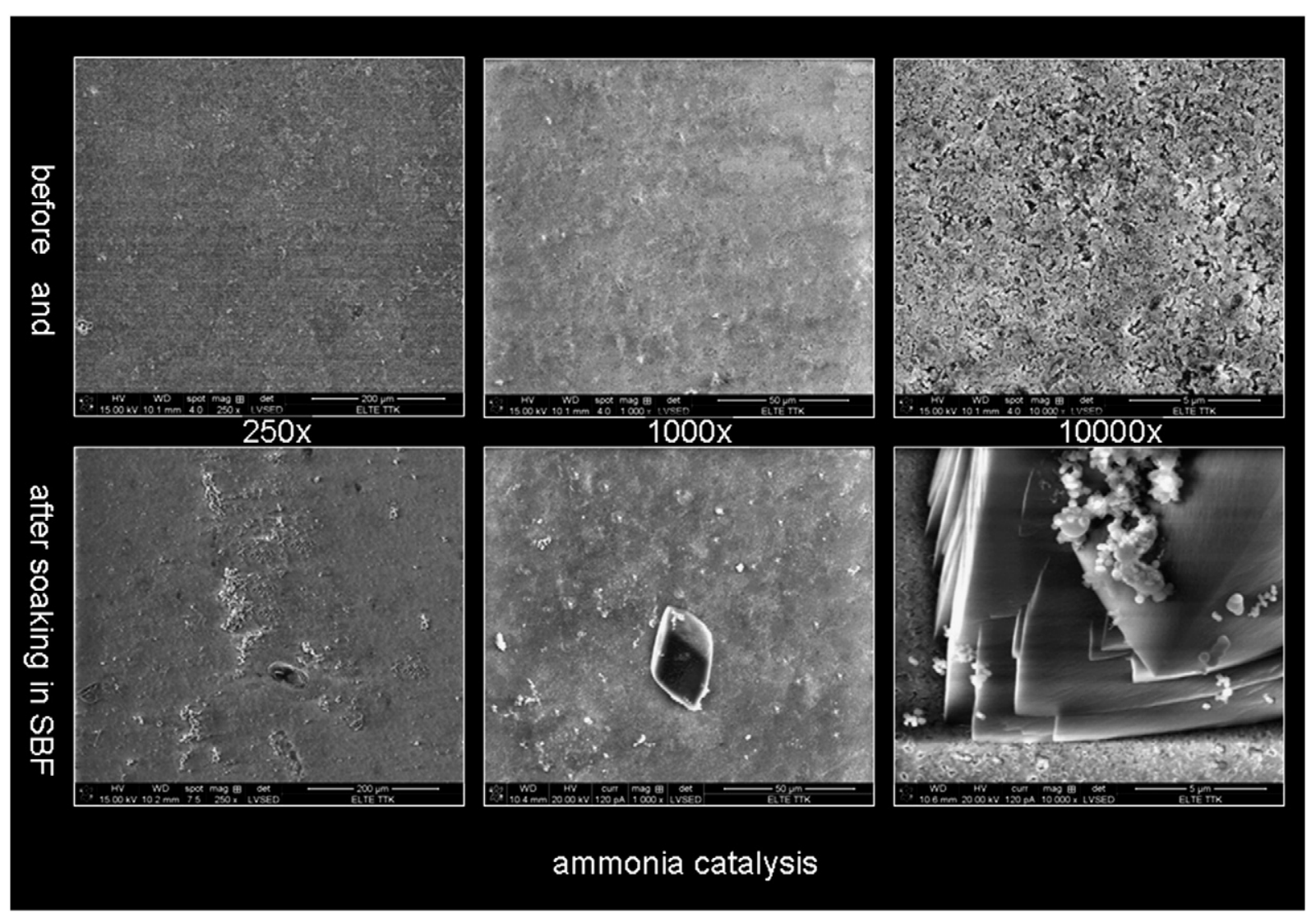

Fig. 7. SEM images of various magnifications for ammonia-catalyzed samples before and after soaking in SBF for 3 days.

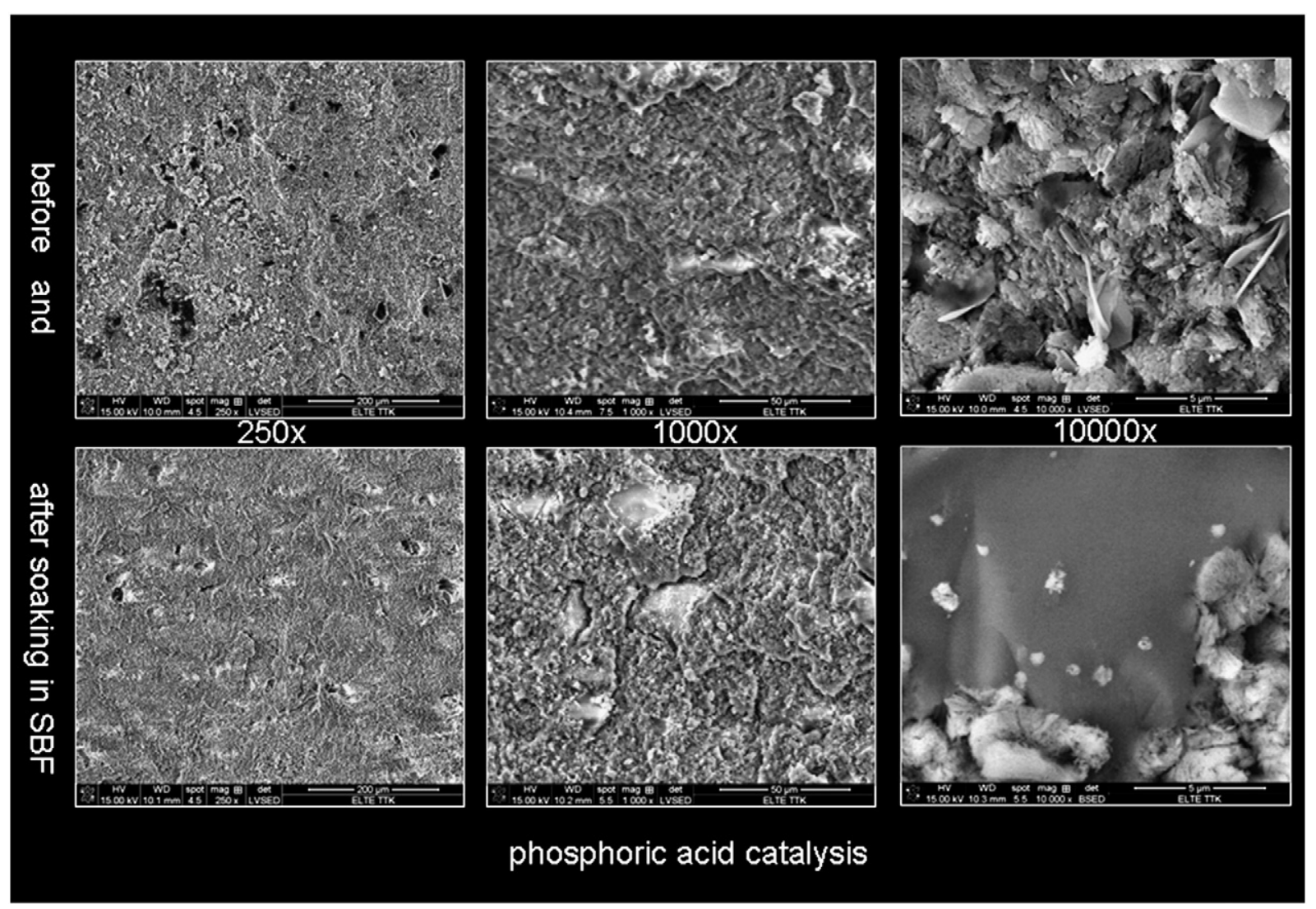

Fig. 8. SEM images of various magnifications for phosphoric acid-catalyzed samples before and after soaking in SBF for 3 days. 
The big differences in the mechanical properties may be explained by the porosity, especially by the pore sizes. The large (>100 nm) and polydisperse pores considerably reduce the mechanical strength. However, the large pores (50-100 $\mu \mathrm{m}$ ) are crucial for an excellent osteointegration. The pore system desired for the fast osteointegration could be prepared only on the surface of the ceramic body considering the requirement of the long-term implants for the good mechanical strength. The crystallinity has also effect on the hardness, the larger crystals $(>100 \mathrm{~nm}$ ) distort the homogeneous texture and decrease the mechanical strength.

The treatment of calcium silicate bioceramics in SBF leads to precipitation of phosphate and slight carbonate particles. The calcium ions released in SBF solution are replaced by $\mathrm{H}^{+}$ion and produce silanol (Si-OH) groups. The silanol groups on the ceramic surface are essential for the formation of hydroxyapatite, hereby improving the bioactivity.

\section{Conclusions}

The bioceramics based on silicate matrix can be utilized as long-term implants due to their slight and slow solubility of silicates in the human body fluid. The aims of the present work were to synthesize bulk calcium silicate bioceramics by new sol-gel route and to understand the correlations between the nanostructure (porosity, morphology or aggregate size) and the macroscopic properties (solubility in water and simulated body fluids, SBF; Vickers-hardness, HV). Varying the preparation conditions, the catalyst proved to be the most efficient parameter in the influence of the ceramic structure and mechanical properties. Basic $\left(\mathrm{NH}_{3}\right)$ and acidic $\left(\mathrm{CH}_{3} \mathrm{COOH}, \mathrm{H}_{3} \mathrm{PO}_{4}\right)$ catalysts were applied in the research work.

Ammonia of the different catalysts provides the bulk ceramics with good mechanical properties and low solubility required for a biomedical application. The ammonia-catalyzed systems are principally amorphous. The fine porosity $(\sim 50 \mathrm{~nm})$ induces the good mechanical character. The ceramic properties depend not only on the type of catalyst but ammonia concentration, too. The ammonia catalyst used in 1.0 or

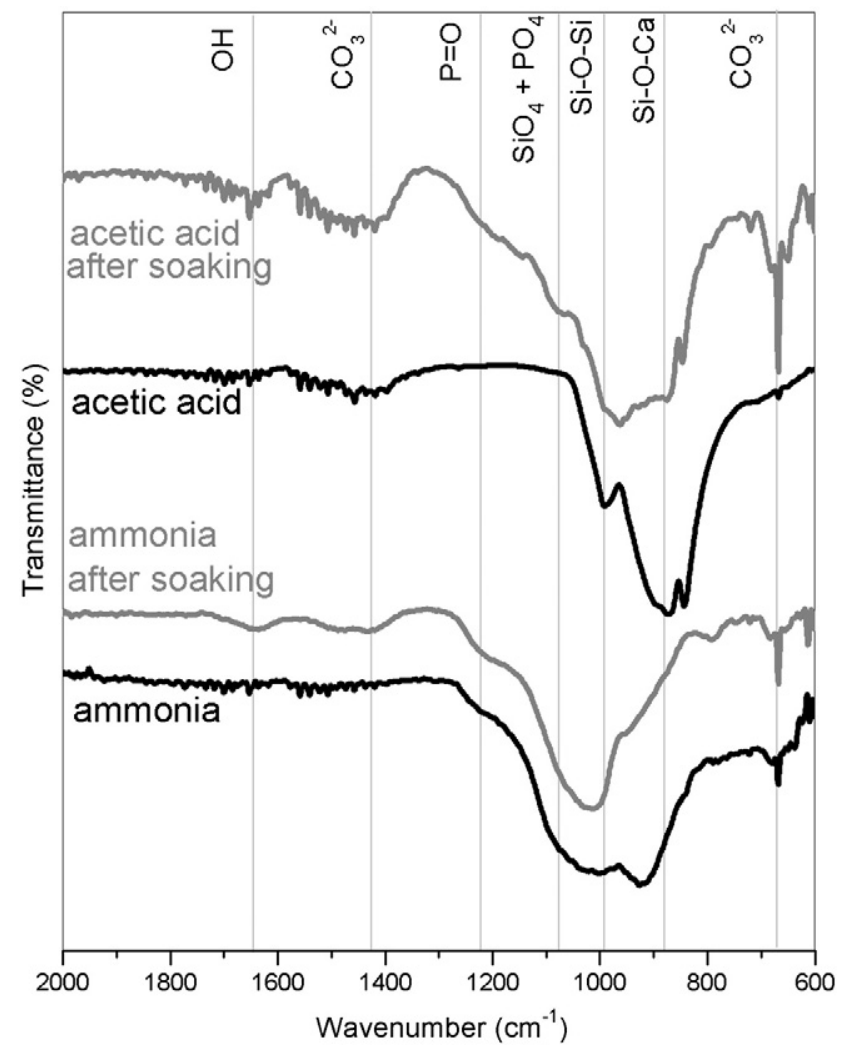

Fig. 9. FTIR spectra of bulk ceramics sintered and soaked in SBF.
10.0 mole ratio of $\mathrm{NH}_{3} / \mathrm{Ca}$ results in the largest hardness ( $\left.200 \mathrm{HV}\right)$, similar porosity (17-20\%) to that of human cortical bone and low solubility (1-3\%) in water and SBF. The use of 1.0 or 10.0 molar ratio leads directly to the formation of a temporary calcium silicate amorphous phase, which transforms to smaller crystals $\left(\beta-\mathrm{Ca}_{2} \mathrm{SiO}_{4}\right)$ only at higher temperature (around $700{ }^{\circ} \mathrm{C}$ ).

In the respect of biomedical application, the main disadvantage of the acetic acid-catalyzed systems is their bed mechanical strength (45-50 HV). The reduction of the mechanical strength derives from the larger and polydisperse pores (20-2000 nm, on average $165 \mathrm{~nm})$. The characteristic crystalline phase is $\beta-\mathrm{Ca}_{2} \mathrm{SiO}_{4}$ formed at $300{ }^{\circ} \mathrm{C}$ and the crystals are growing up to the temperature of sintering. The advantages of the bulk ceramics catalyzed by acetic acid are the homogeneous gel structure, low solubility ( $\sim 4 \%$ ) in water and SBF, and an apatite layer can be formed on their surface in SBF.

The phosphoric acid-catalyzed ceramic systems can not be utilized as an implant owing to their inhomogeneous structure and larger and long term solution in water. The solubility of the ceramics increases drastically by rising molar ratio of $\mathrm{P} / \mathrm{Si}$. The phosphorous-containing systems possess the largest volume of crystals; $\beta-$ and $\gamma-\mathrm{Ca}_{2} \mathrm{P}_{2} \mathrm{O}_{7}$ phases. Over the crystalline phases, glassy lenses can be displayed in the texture. The inhomogeneous structure results in changing HV values (on average $120 \mathrm{HV}$ ). The pores in the samples of phosphoric acid are generally large $(\sim 310 \mathrm{~nm})$ but less polydisperse.

\section{Acknowledgment}

This study has been supported by I-04-009 EU in HASYLAB, DESY and OTKA NK 101704 funds. The European Union and the European Social Fund have provided financial support to the project under the grant agreement no. TÁMOP 4.2.1./B-09/KMR-2010-0003.

\section{References}

[1] I. Izquierdo-Barba, A.J. Salinas, M. Vallet-Regi, J. Biomed. Mater. Res. 47 (1999) 243-250.

[2] A. Martínez, I. Izquierdo-Barba, M. Vallet-Regi, Chem. Mater. 12 (2000) 3080-3088.

[3] A.J. Salinas, M. Vallet-Regí, I. Izquierdo-Barba, J. Sol-Gel Sci. Technol. 21 (2001) 13-25.

[4] M. Vallet-Regi, V.C. Ragel, A.J. Salinas, Eur. J. Inorg. Chem. 2003 (2003) 1029-1042.

[5] N. Olmo, A.I. Martín, A.J. Salinas, J. Turnay, M. Vallet-Regí, M.A. Lizarbe, Biomaterials 24 (2003) 3383-3393.

[6] M. Vallet-Regi, A.J. Salinas, A. Martínez, I. Izquierdo-Barba, J. Pérez-Pariente, Solid State Ionics 172 (2004) 441-444

[7] H. Yan, K. Zhang, C.F. Blanford, L.F. Francis, A. Stein, Chem. Mater. 13 (2001) 1374-1382.

[8] T. Kokubo, J. Non-Cryst. Solids 120 (1990) 138-151.

[9] M. Catauro, G. Laudisio, J. Sol-Gel Sci. Technol. 10 (1997) 231-237.

[10] M.I. Alemany, P. Velasquez, M.A. de la Casa-Lillo, P.N. De Aza, J. Non-Cryst. Solids 351 (2005) 1716-1726.

[11] M. Vallet-Regí, A. Rámila, Chem. Mater. 12 (2000) 961-965.

[12] J. Pérez-Pariente, F. Balas, M. Vallet-Regí, Chem. Mater. 12 (2000) 750-755.

[13] M. Vallet-Regí, D. Arcos, J. Pérez-Pariente, J. Biomed. Mater. Res. 51 (2000) 23-28.

[14] D. Baciu, J. Simitzis, J. Optoelectron. Adv. Mater. 9 (2007) 3320-3324.

[15] P. Siriphannon, Y. Kameshima, A. Yasumori, K. Okada, S. Hayashi, J. Eur. Ceram. Soc. 22 (2002) 511-520.

[16] A.G. Kalampounias, N. Bouropoulos, K. Katerinopoulou, S.N. Yannopoulos, J. Non-Cryst. Solids 354 (2008) 749-754.

[17] A. Meiszterics, K. Sinkó, Colloids Surf., A 319 (2008) 143-148.

[18] K. Sinkó, A. Meiszterics, L. Rosta, Progr. Colloid. Polym. Sci. 135 (2008) 130-138.

[19] A. Meiszterics, L. Rosta, H. Peterlik, J. Rohonczy, S. Kubuki, P. Henits, K. Sinkó, J. Phys. Chem. A 114 (2010) 10403-10411.

[20] T. Kokubo, H. Kushitani, S. Sakka, T. Kitsugi, T. Yamamuro, J. Biomed. Mater. Res. 24 (1990) 721-734.

[21] M. Figueiredo, J. Henriques, G. Martins, F. Guerra, F. Judas, H. Figueiredo, J. Biomed Mater. Res. B: Appl. Biomater. 92 (2010) 409-419.

[22] S.T. Li, H.C. Chen, D. Pierson, D. Yuen, P. Hansen, NuOss ${ }^{\mathrm{TM}}$, a Bone Grafting Material for Oral Surgery: A Comparative Study with BioOss. Available from URL: http://www. stomascience.com/uploads/documents/Research/Comparative\%20Study\%20with\%20 BioOss.pdf.

[23] E. Dahi, H. Bregnhøj, 1st International Workshop on Fluorosis Prevention and Defluoridation of Water; 1st Proceedings (2010) 96-103.

[24] H.B. Breitz, R.E. Wendt, M.S. Stabin, S. Shen, W.D. Erwin, J.G. Rajendran, J.F. Eary, L Durack, E. Delpassand, W. Martin, R.F. Meredith, J. Nucl. Med. 47 (2006) 534-542.

[25] S. Hall, Basic Biomechanics, Fifth edition McGraw-Hill Humanities/Social Sciences/ Languages, 2007.

[26] Z.B. Friedenberg, W.H. Simon, Surg. Gynecol. Obstet. 116 (1963) 588-592. 
[27] S. Hulbert, in: A.L. Bement Jr. (Ed.), Biomaterials, University of Washington Press, Seattle, 1971 , pp. 3-77.

[28] I. Izquierdo-Barba, M. Colilla, M. Vallet-Regí, J. Nanomater. 2008 (2008) 1-14.

29] S.V. Dorozhkin, Materials 2 (2009) 399-498.

[30] D.M. Liu, Mater. Chem. Phys. 36 (1994) 294-303.
31] P.N. De Aza, F. Guitian, S. De Aza, Scr. Metall. Mater. 31 (1994) 1001-1005.

[32] I. Izquierdo-Barba, M. Vallet-Regi, J. Biomed. Mater. Res. 47 (1999) 243-250.

[33] P.N. De Aza, Z.B. Luklinska, M. Anseau, F. Guitian, S. De Aza, J. Dent. 27 (1999) 107-113.

[34] M.M. Pereira, L.L. Hench, J. Sol-Gel Sci. Technol. 7 (1996) 59-68. 